\title{
The effect of the natural extracts of garlic or Eucalyptus on the growth, yield and some chemical constituents in quinoa plants
}

Kowthar Gad El-Rokiek ${ }^{*}$ (D, Mona Gergis Dawood, Mervat Shamoon Sadak and Mohamed El-Sayed El-Awadi

\begin{abstract}
Background: Quinoa seeds contain highly nutritive compounds, so it acquired increasing interest during the last years

Materials and methods: A field experiment was conducted at the experimental station of Agricultural Production and Research Station, National Research Centre, El Nubaria Province, El Behaira Governorate, Egypt, during two successive winter seasons (2016/2017 and 2017/2018). In this experiment, quinoa plants were sprayed with clove extract of garlic or leaf extract of Eucalyptus globulus with concentrations 5, 10 and 15\% in addition to the untreated control treatment. Quinoa plants were sprayed twice 86 and 93 DAS (days after sowing).

Results: The results of vegetative growth stages indicated increases in quinoa growth due to the treatments with different concentrations of the two mentioned extracts. The results also revealed increases in photosynthetic pigments constituents (chlorophyll a, chlorophyll b and carotenoids) of quinoa leaves. The results also indicated increases in yield and oil content as well as different studied metabolic activity.

Conclusion: We can conclude from these results that spraying quinoa plants with natural clove extract of garlic or leaf extract of Eucalyptus for increasing growth and consequently yield.
\end{abstract}

Keywords: Garlic, Eucalyptus, Quinoa, Growth, Yield, Biochemical constituents

\section{Background}

Quinoa (Chenopodium quinoa Willd.) is an annual dicotyledonous herbaceous crop of the Amaranthaceae family and local to the Andean region in South Africa (Fuentes et al. 2012). Quinoa is a great wheat-free alternative to starchy grains. Increasing yield for an evergrowing world population has currently become a topic of great concern with regard to food security. Especially in Africa, agricultural productivity has not been able to cope with population growth, leading to increase in annual imports and food insecurity (Elewa et al. 2017).

Quinoa seeds contain highly nutritive compounds, so it acquired increasing interest during the last years

\footnotetext{
*Correspondence: kowtharelrokiek@gmail.com; ahmed_ezat2000@yahoo.com

Botany Department, National Research Centre, 33 El Bohooth St. (former El Tahrir St.), Dokki, Cairo 12622, Egypt
}

\section{Springer Open}

(Nowak et al. 2016). Quinoa contains all ten essential amino acids, and its protein content ranges from 12.9 to 16.5\% (Saturni et al. 2010 and Vega-Gálvez et al. 2010). In addition, its high content of the two essential amino acids lysine and methionine are deficient in many grains and legumes (Gesinski and Nowak 2011; Sánchez-Chino et al. 2015). Quinoa seeds have high biological protein value (73\%) that is higher than rice, wheat and corn (56, 49 and 36\% respectively) as have been reported by Vega-Gálvez et al. (2010) and Gesinski and Nowak (2011). It contains also high concentration of unsaturated fatty acids. The total lipid content of quinoa is $14.5 \%$, with about $70-89.4 \%$ unsaturated fatty acids and contains many vitamins, such as thiamine, folic acid, vitamin $C$, vitamin $B_{6}$ and vitamin $E$ (VegaGálvez et al. 2010). In the same trend, it contains mineral as calcium, magnesium and potassium in 
sufficient quantities and in bioavailable forms necessary for maintaining a balanced human diet (González Martín et al. 2014 and Nascimento et al. 2014) and large antioxidant capacity (Vega-Gálvez et al. 2010; Tang et al. 2016 and González Martín et al. 2014).

Plants produce metabolites which are inhibitors or stimulators depending on their concentrations. Some of these compounds are produced at certain concentrations that are phytotoxic to receiving organisms or stimulators (Rice 1984) and subsequently alter the growth or physiological functions of receiving species. These metabolites are extracted from different allelopathic plants such as Eucalyptus globulus.

The Eucalyptus species possess high allelopathic activity (Sasikumar et al. 2001 and Singh et al. 2005). Chromatographic analysis showed the presence of coumaric, gallic, gentisic, hydroxybenzoic, syringic and vanillic acids in Eucalyptus globulus leaf extract (Sasikumar et al. 2001 and El-Rokiek et al. 2011).

The garlic extract is the sap of garlic bulb Allium sativum (L.), which belongs to the family Liliaceae. It is distinguished by containing a high amount of amino acids, which contain sulphur element, such as cysteine and methionine (Synge 1971). As well, garlic contains the following materials: volatile oil, allicin, alliin, sugar, iodine and vitamins (Al Mayahi and Fayadh 2015). As mentioned by Abou Hussein et al. (1975a, 1975b), the garlic extract has many effects due to its hormonal (auxin-like) nature, which has an important role in lateral extension and elongation of cells. Concerning garlic acid effect, Helmy (1992) reported that application of fresh garlic clove extract solution either in ethyl alcohol or tap water to summer squash cv. Eskandarani plants at $250 \mathrm{mg}$ $\mathrm{DW} /$ plant gave the best results in increasing the number of flowers. Ahmed et al. (2005) found that a greater increase in the number of pods of pea (cv. Meteor) was obtained with post-inoculation treatment with garlic extract at $10 \mathrm{~g} / \mathrm{l}$. Treatment of Majorana hortensis and Salvia officinalis by garlic extract at the concentration of 50 or $100 \%$ increased fresh, and dry weights, photosynthetic pigments of chlorophylls $\mathrm{a}$ and $\mathrm{b}$ and total soluble carbohydrates content in the first and second cut as well as the total oil content (Mady 2009).

\section{Objective}

This work aimed to increase quinoa yield by using low concentrations of garlic cloves and Eucalyptus globulus leaf extracts.

\section{Material and methods}

Allium sativum (garlic) plants were allowed for complete dryness in shadow, then the cloves were separated, cut and ground. Water extracts at concentrations of 15, 30, 45 and $60 \%$ were prepared.

A field experiment was carried out at the experimental station of Agricultural Production and Research Station, National Research Centre, El Nubaria Province, El Behaira Governorate, Egypt, at two successive winter seasons (2016/2017 and 2017/2018). Quinoa (Chenopod quinoa) cultivar (cv. Quinoa 1) was obtained from the Egyptian Ministry of Agriculture. The soil was ploughed twice, ridged and divided into plots. The area of each plot was $10.5 \mathrm{~m}^{2}$ (15 rows; $3.5-\mathrm{m}$ long and $20 \mathrm{~cm}$ apart between rows). Quinoa grains were cultivated during the first week of December (7 December 2016 and 2017). The plants were sprayed on both surfaces of the leaves with different concentrations of garlic clove water extract or Eucalyptus globulus water leaf extract at concentrations $0,5,10$ and $15 \%$ twice at 86 and 93 days after sowing. The experimental design in this study was a randomized complete block design with four replicates. Samples of ten plants were taken at random from each plot of the four replications for determination of vegetative growth parameters (plant height, number of branches/plant, plant fresh and dry weight) and photosynthetic pigments.

At harvest, the weight of seeds/plant as well as the weight of 1000 seeds were taken. In addition, some chemicals in the analysis were determined in the yielded seeds such as carbohydrates\%, oil \%, some element content such as nitrogen, phosphorus and potassium, total phenolic contents, and flavonoids contents as well as antioxidant activity.

\section{Measurements}

\section{Photosynthetic pigments}

Total chlorophyll a and b and carotenoid contents in fresh leaves were estimated using the method of Lichtenthaler and Buschmann (2001). The fresh tissue was ground in a mortar and pestles using $80 \%$ acetone. The optical density (OD) of the solution was recorded at 662 and $645 \mathrm{~nm}$ (for chlorophylls a and b, respectively) and $470 \mathrm{~nm}$ (for carotenoids) using a spectrophotometer (Shimadzu UV-1700, Tokyo, Japan). The values of photosynthetic pigments were expressed in milligrams per gram fresh weight.

\section{Total carbohydrate}

Determination of total carbohydrates was carried out according to Herbert et al. (1971). A known mass $(0.2-0.5 \mathrm{~g})$ of dried tissue was placed in the test tube, and then $10 \mathrm{ml}$ of sulphuric acid $(1 \mathrm{~N})$ was added. The tube was sealed and placed overnight in an oven at $100{ }^{\circ} \mathrm{C}$. The solution was then filtered into a measuring flask $(100 \mathrm{ml})$ and completed to the mark with distilled water. The total sugars were determined 
colourimetrically according to the method of Dubois et al. (1956) as follows: an aliquot of $1 \mathrm{ml}$ of sugar solution was transferred into a test tube and treated with $1 \mathrm{ml}$ of $5 \%$ aqueous phenol solution followed by $5.0 \mathrm{ml}$ of concentrated sulphuric acid. The tubes were thoroughly shaken for $10 \mathrm{~min}$ then placed in a water bath at $23-30{ }^{\circ} \mathrm{C}$ for 20 min. The optical density of the developed colour was measured at $490 \mathrm{~nm}$ using Shimadzu spectrophotometer model UV 1201.

\section{Oil determination}

The oil of quinoa seeds was extracted according to Kates and Eberhardt (1957); the powdered seeds are shaken overnight with isopropanol to chloroform (1:1). The solvent was evaporated under reduced pressure of the $\mathrm{CO}_{2}$ atmosphere. The lipid residue is taken up in chloroform to methanol $(2: 1 v / v)$ and given a Folch wash; the dissolved total oils were purified by washing with $1 \%$ aqueous saline solution. The aqueous phases were washed with chloroform that was combined with the pure oil solution. Chloroform was evaporated and the total pure oil was weighed.

\section{Element contents}

Nitrogen, phosphorus and potassium contents were determined according to the official and modified methods of analysis (A.O.A.C. 1984).

\section{Total phenolic contents}

Total phenolic contents were extracted from dry seeds. A known weight was taken and extracted with $85 \%$ cold methanol $(v / v)$ three times at $0^{\circ} \mathrm{C}$. The combined extracts were collected and made up to a known volume with cold methanol. Then, $0.5 \mathrm{ml}$ of the extraction was added to $0.5 \mathrm{ml}$ Folin, shaken and allowed to stand for 3 min. Then, $1 \mathrm{ml}$ of saturated sodium carbonate was added to each tube followed by distilled water shaken and allowed to stand for $60 \mathrm{~min}$. The optical density was determined at a wavelength of $725 \mathrm{~nm}$ using a spectrophotometer as described by Danil and George (1972).

\section{Free radical scavenging activity (DPPH\%)}

The free radical scavenging activity by different plant extracts was done according to the method reported by Gyamfi et al. (2002). Fifty microlitres of the plant extract in methanol, yielding $100 \mu \mathrm{g} / \mathrm{ml}$ respectively in each reaction, was mixed with $1 \mathrm{ml}$ of $0.1 \mathrm{mM}$ diphenyl-2-picrylhydrazyl (DPPH) in methanol solution and $450 \mu \mathrm{l}$ of $50 \mathrm{mM}$ Tris$\mathrm{HCl}$ buffer ( $\mathrm{pH} 7.4)$. Methanol $(50 \mu \mathrm{l})$ only was used as control of the experiment. After $30 \mathrm{~min}$ of incubation at room temperature, the reduction of the DPPH free radical was measured reading the absorbance at $517 \mathrm{~nm}$. L-ascorbic acid and BHT were used as controls. The percent inhibition was calculated from the following equation:

$$
\begin{aligned}
\text { \%inhibition }= & {[\text { absorbance of control }} \\
& \text {-absorbance of test sample } \\
& \text { /absorbance of control }] \times 100
\end{aligned}
$$

\section{Flavonoids contents}

The flavonoid content of the crude extract was determined by the aluminium chloride colourimetric method (Chang et al. 2002). In brief, $50 \mu \mathrm{L}$ of crude extract $(1 \mathrm{mg} / \mathrm{mL}$ ethanol) was made up to $1 \mathrm{~mL}$ with methanol, mixed with $4 \mathrm{~mL}$ of distilled water and then $0.3 \mathrm{~mL}$ of $5 \% \mathrm{NaNO}_{2}$ solution; $0.3 \mathrm{~mL}$ of $10 \%$ $\mathrm{AlCl}_{3}$ solution was added after $5 \mathrm{~min}$ of incubation, and the mixture was allowed to stand for $6 \mathrm{~min}$. Then, $2 \mathrm{~mL}$ of $1 \mathrm{~mol} / \mathrm{L} \mathrm{NaOH}$ solution was added, and the final volume of the mixture was brought to $10 \mathrm{~mL}$ with double-distilled water. The mixture was allowed to stand for $15 \mathrm{~min}$, and absorbance was measured at $510 \mathrm{~nm}$. The total flavonoid content was calculated from a calibration curve, and the result was expressed as milligram Rutin equivalent per gram dry weight.

\section{Statistical analysis}

Statistical analysis was statistically analyzed at 5\% probability according to Snedecor and Cochran (1980).

\section{Results}

The results in Table 1 indicate that the vegetative growth characters shoot length, number of branches and fresh and dry weight of quinoa plant significantly increased at all concentrations of garlic clove extract as well as Eucalyptus leaf extract. The increase in these parameters reached maximum significant value using 15\% of garlic clove extract or $10 \%$ of Eucalyptus leaf extract in comparison to the untreated control.

Data reveal that spraying quinoa plants with different concentrations of garlic clove extract or Eucalyptus leaf extract caused significant increases in the contents of chlorophyll a, chlorophyll b and carotenoids in quinoa leaves over untreated control. The remarkable significant increase was measured at $15 \%$ garlic clove extract or Eucalyptus leaf extract (Table 2).

Spraying garlic clove extract and Eucalyptus leaf extract at different concentrations showed significant increases in both plant height and number of branches/ plant as well as dry weight/plant at the end of the season (Table 3). In addition, seed yield/plant and weight of 1000 seeds of quinoa plants revealed significant responses in comparison to their corresponding controls. The highest significant increase in seed yield/plant exceeded $100 \%$ of the untreated plant $(121.6 \%)$ with the treatment of garlic extract at $15 \%$. The weight of 1000 seeds realized corresponding results (58.8\%) over an 
Table 1 Effect of natural extracts of garlic and Eucalyptus on the vegetative growth of quinoa

\begin{tabular}{|c|c|c|c|c|c|}
\hline Treatments & Concentration (\%) & Shoot length & No. of branches & Fresh wt. (g) & Dry wt. (g) \\
\hline Control & 0 & 26.52 & 4.67 & 5.52 & 1.03 \\
\hline \multirow[t]{3}{*}{ Garlic clove extract } & 5 & 32.52 & 5.33 & 6.45 & 1.85 \\
\hline & 10 & 39.55 & 5.33 & 6.95 & 1.54 \\
\hline & 15 & 36.52 & 6.52 & 7.52 & 1.65 \\
\hline \multirow[t]{3}{*}{ Eucalyptus leaf extract } & 5 & 34.52 & 5.32 & 6.41 & 2.14 \\
\hline & 10 & 38.52 & 5.67 & 7.52 & 2.34 \\
\hline & 15 & 35.24 & 6.24 & 7.68 & 2.45 \\
\hline \multicolumn{2}{|c|}{ LSD at $5 \%$} & 0.69 & 0.73 & 0.13 & 0.07 \\
\hline
\end{tabular}

untreated plant with this later treatment. The increase in growth and yield was accompanied with a significant increase in the contents of total carbohydrates over the contents in seeds of untreated plants.

Quantitative estimation of oil in quinoa seeds revealed a significant increase in oil content by the natural extract of garlic and Eucalyptus application over the untreated control. The maximum significant increase was found with the treatment of garlic clove extract at $15 \%$ (Table 4). Regarding nitrogen and protein, the treatments of garlic and Eucalyptus showed significant increases over the untreated seeds with an elevated level at $10 \%$ of garlic cloves. Similarly, phosphorus and potassium recorded high significant increase over their corresponding controls reaching to marked level using Eucalyptus extract at $10 \%$. The antioxidant activity and flavonoids as well as phenolic compound contents indicated significant increases over their corresponding controls. The treatment with Eucalyptus extract at $10 \%$ resulted in the maximum levels of the later three constituents (Table 4).

\section{Discussion}

Garlic (Allium sativum L.) extract as well as Eucalyptus globulus are thought to be good allelochemicals resources
(Wang et al. 2014; El-Rokiek et al. 2011) and consequently can efficiently realize good management in agricultural sustainable development.

The results in Table 1 revealed a significant increase in quinoa growth represented by plant height, number of branches and fresh and dry weight by using leaf extract of Eucalyptus and garlic clove extract. The results also indicate an increase in photosynthetic pigment contents. This growth improvement in quinoa plants can be established by the fact that garlic extracts contain various growth-promoting compounds such as starch and vitamins and organosulphur compounds such as allicin and diallyl disulphide, etc. (Puva ca et al. 2014; Martins et al. 2016). However, in the current findings, there seems to be a strong correlation between the morphological indices and the developmental aspects such as chlorophyll or carotenoid contents. Several documented results revealed an increase in plant growth by using garlic extract, for example, increase in the number of flowers in summer squash cv. Eskandarani (Helmy 1992). Similar results also on squash were also obtained by ElDesouky et al. (1998). In addition, garlic extract at $10 \mathrm{~g} / \mathrm{L}$ caused a great increase in the number of pods of pea plants (Ahmed et al. 2005). Similar results were obtained by Mady (2009) on Majorana hortensis and Salvia officinalis. Likewise, Hanafy et al. (2012) reported that the highest values

Table 2 Effect of natural extracts of garlic and Eucalyptus on contents of chlorophyll a, chlorophyll b and carotenoids in quinoa leaves

\begin{tabular}{llllll}
\hline Treatments & $\begin{array}{l}\text { Concentration } \\
(\%)\end{array}$ & $\begin{array}{l}\text { Chl. a }(\mathrm{mg} / \mathrm{g} \text { fresh } \\
\text { wt.) }\end{array}$ & $\begin{array}{l}\text { Chl. b (mg/g fresh } \\
\text { wt.) }\end{array}$ & $\begin{array}{l}\text { Carotenoids }(\mathrm{mg} / \mathrm{g} \text { fresh } \\
\text { wt.) }\end{array}$ & $\begin{array}{l}\text { Total pigments (mg/g fresh } \\
\text { wt.) }\end{array}$ \\
\hline Control & 0 & 12.52 & 8.54 & 4.52 & 25.58 \\
Garlic clove extract & 5 & 13.52 & 8.96 & 5.15 & 27.63 \\
& 10 & 14.52 & 10.15 & 5.95 & 30.62 \\
& 15 & 15.42 & 10.95 & 6.12 & 32.49 \\
Eucalyptus leaf & 5 & 13.45 & 9.01 & 4.97 & 27.43 \\
extract & 10 & 14.47 & 10.15 & 5.32 & 29.94 \\
& 15 & 15.95 & 10.74 & 6.54 & 33.23 \\
LSD at 5\% & 0.43 & 0.10 & 0.27 & 0.55 \\
\hline
\end{tabular}


Table 3 Effect of natural extracts of garlic and Eucalyptus on yield and yield components of quinoa plants

\begin{tabular}{llllllll}
\hline Treatments & $\begin{array}{l}\text { Concentration } \\
(\%)\end{array}$ & $\begin{array}{l}\text { Plant height } \\
(\mathrm{cm})\end{array}$ & $\begin{array}{l}\text { No. branches/ } \\
\text { plant }\end{array}$ & $\begin{array}{l}\text { Dry wt. (g)/ } \\
\text { plant }\end{array}$ & $\begin{array}{l}\text { Wt. of seeds } \\
(\mathrm{g})\end{array}$ & $\begin{array}{l}\text { Wt. of 1000 } \\
\text { seeds (g) }\end{array}$ & $\begin{array}{l}\text { Carbohydrates } \\
(\%)\end{array}$ \\
\hline Control & 0 & 53.66 & 10.66 & 9.68 & 4.66 & 2.33 & 60.25 \\
Garlic clove extract & 5 & 45.66 & 21.66 & 10.28 & 5.81 & 2.69 & 62.52 \\
& 10 & 54.00 & 29.00 & 16.75 & 8.65 & 3.02 & 62.78 \\
& 15 & 64.00 & 30.66 & 20.01 & 10.33 & 3.70 & 63.52 \\
Eucalyptus leaf & 5 & 50.33 & 18.66 & 10.15 & 6.52 & 3.13 & 61.52 \\
extract & 10 & 54.33 & 26.00 & 17.52 & 8.74 & 2.63 & 63.54 \\
& 15 & 42.33 & 15.00 & 9.05 & 6.85 & 3.44 & 6.47 \\
LSD at 5\% & 2.61 & 3.24 & 2.73 & 0.53 & 0.14 & 6.40
\end{tabular}

of plant height, stem diameter, dry weight of leaves/plant, leaf area, total carbohydrates and $\mathrm{N}$ contents in Schefflera arboricola were obtained with garlic extract. Moreover, Sikandar et al. (2018) garlic extract treatment increased the growth parameters of pepper plant.

The Eucalyptus species possess high allelopathic activity that might be inhibitors or stimulatory according to concentrations (Singh et al. 2005). These allelopathic extracts contained different phenolic acids which might be phytotoxic or promoters (Sasikumar et al. 2001). In the present work, the used concentrations were promoters for quinoa growth, therefore increasing growth parameters, photosynthetic pigments and consequently yield.

The allelochemical materials in allelopathic plants might be phenolic acids as have been reported by many workers (Chon et al. 2003; Hegazy and Farrag 2007). In addition, the analysis of Eucalyptus globulus leaf extract by El-Rokiek et al. (2014) revealed the presence of phenolic acids such as caffeic, ferulic, benzoic, chlorogenic, hydroxybenzoic and cinnamic acids. Phenolic compounds played a significant role in the regulation of plant metabolic processes and act as a substrate for many antioxidants enzymes (Khattab 2007). Sharma et al. (2015) suggest that phenolic acid, e.g. ferulic acid at low concentration, can be used for improving the performance of wheat under various environmental constraints. Also, it was found that some phenolic acids at low concentrations stimulated primary root length, number and length of secondary roots and dry weight of Deschampsia flexuosa and Senecio sylvaticus (Kuiters 1989). Salicylic acid as an example at low concentration is an endogenous growth regulator of phenolic nature and acts as a potential non-enzymatic antioxidant that participates in the regulation of many physiological processes in plants, such as stomatal closure, photosynthesis, ion uptake, inhibition of ethylene biosynthesis, transpiration and stress tolerance (Khan et al. 2003; Arfan et al. 2007). These results coincided with our obtained current results (Tables 2, 3 and 4).

In addition, the increases in metabolic activity of quinoa might have resulted from a corresponding increase in photosynthetic pigments (Table 2) which in turn increased carbohydrate contents in addition to the increase in protein due to the increase in nitrogen content (Coruzzi and Last 2000).

Table 4 Effect of natural extracts of garlic and Eucalyptus on the different chemical constituents of quinoa seeds at the end of the season

\begin{tabular}{|c|c|c|c|c|c|c|c|c|c|}
\hline \multirow[t]{2}{*}{ Treatments } & \multirow{2}{*}{$\begin{array}{l}\text { Concentration } \\
\text { (\%) }\end{array}$} & \multicolumn{6}{|c|}{ Percentage (\%) } & \multicolumn{2}{|c|}{ Milligrams per gram dry weight } \\
\hline & & Oil & Protein & $\mathrm{N}$ & $P$ & K & DPPH & Flavonoids & Phenolics \\
\hline Control & 0 & 8.48 & 14.49 & 236.22 & 266.55 & 398.63 & 34.28 & 41.69 & 111.25 \\
\hline \multirow[t]{3}{*}{ Garlic clove extract } & 5 & 9.02 & 15.42 & 248.95 & 286.45 & 421.35 & 43.12 & 45.91 & 123.32 \\
\hline & 10 & 9.67 & 16.58 & 263.63 & 321.47 & 439.30 & 47.02 & 50.31 & 136.87 \\
\hline & 15 & 9.69 & 15.99 & 258.62 & 304.29 & 416.05 & 44.26 & 47.62 & 127.67 \\
\hline \multirow[t]{3}{*}{ Eucalyptus leaf extract } & 5 & 9.14 & 15.67 & 253.17 & 303.33 & 435.61 & 44.89 & 47.05 & 123.83 \\
\hline & 10 & 9.89 & 17.17 & 274.74 & 336.01 & 451.13 & 50.20 & 55.44 & 141.90 \\
\hline & 15 & 9.56 & 16.17 & 260.13 & 315.34 & 443.67 & 46.55 & 51.01 & 129.30 \\
\hline LSD at $5 \%$ & & 0.13 & 0.37 & 2.69 & 3.74 & 1.89 & 0.50 & 0.82 & 0.86 \\
\hline
\end{tabular}


In general, the increase in plant growth was accompanied by increases in metabolic activity which represented by different chemical constituents (El-Rokiek et al. 2012).

\section{Conclusion}

The results of the current study suggested using clove extract of garlic or leaf extract of Eucalyptus for increasing quinoa growth and consequently yield.

\section{Abbreviations}

Chl.: Chlorophyll; cv: Cultivar; DPPH: Diphenyl-2-picryl-hydrazyl; K: Potassium; N: Nitrogen; No.: Number; P: Phosphorus; Wt.: Weight

\section{Acknowledgements}

The authors are thankful to the National Research Centre for the provision of laboratory facilities to carry out this research

\section{Authors' contributions}

KGER, MSS, MGD and MEEA performed the laboratory analysis, wrote the paper, performed the data and coordinated the data collection. All authors read and approved the final manuscript.

\section{Authors' information}

Kowthar G. El-Rokiek is a Professor of Weed Biology and Control at the National Research Centre, Egypt.

Mervat Sh. Sadak, Mona G. Dawood and Mohamed E El-Awadi are Professors of Plant Physiology at the National Research Centre, Egypt.

\section{Funding}

There are currently no funding sources in the design of the study and collection, analysis and interpretation of data and in writing of the manuscript.

\section{Availability of data and materials}

The datasets generated and/or analysed during the current study are included in this published manuscript.

\section{Ethics approval and consent to participate}

Not applicable

\section{Consent for publication}

Not applicable

\section{Competing interests}

The authors declare that they have no competing interests.

Received: 9 May 2019 Accepted: 10 July 2019

Published online: 23 July 2019

\section{References}

Abou Hussein MR, Fadle SM, Walley YA (1975a) Effect of garlic bulb extract on flowering, sex ratio, and yield of squash. I. Effect of different fractions of partitioned garlic bulb extract on flowering in squash. Egypt J Hort 2(1):3-10

Abou Hussein MR, Fadle SM, Walley YA (1975b) Effect of garlic bulb extract on flowering, sex ratio, and yield of squash. II. Modulation of sex ration by application of different fraction of garlic bulb extract. Egypt J Hort 2(1):11-22

Ahmed S, Iqbal J, Attauddin I (2005) Time of application effect of phytobiocides on powdery mildew and yield in pea. Sarhad J Agric 21:729-731

Al Mayahi MA, Fayadh MH (2015) The effects of garlic extract, its application methods and their interaction on growth and yield of potato, Solanum tuberosum (L.) Cv. Latonia. AAB Bioflux 7(1):59-69

AOAC (1984) Association of Official Analytical Chemists - Official methods of analysis of the association of official analytical chemists, Washington DC, 21st edition.

Arfan M, Athar HR, Ashraf M (2007) Does exogenous application of salicylic acid through the rooting medium modulate growth and photosynthetic capacity in two differently adapted spring wheat cultivars under salt stress? J Plant Physiol 164(6):685-694
Chang C, Yang M, Wen H, Chern J (2002) Estimation of total flavonoid content in propolis by two complementary colorimetric methods. J Food Drug Anal 10:178-182

Chon SU, Kim YM, Lee JC (2003) Herbicidal potential and quantification of causative allelochemicals from several Compositae weeds. Weed Res 43(6): 444-448

Coruzzi G, Last R (2000) Amino acids. In: Buchanan B, Gruissem RJ (eds) Biochemistry and molecular biology of plants, American Society of Plant Physiologists (pubs.), Maryland, pp 358-410

Danil AD, George CM (1972) Peach seed dormancy in relation to endogenous inhibitors and applied growth substances. J Am Soc Hort Sci 17:621-624

Dubois M, Gilles KA, Hamilton JK, Robers PA (1956) Colourimetric method for determination of sugars and related substances. Anal. Chem. 28:350-356

El-Desouky SA, Wanas LA, Khedr ZM (1998) Utilization of some natural plant extracts of garlic and yeast as cloves-soaking materials to squash (Cucurbito pepo L.). I. Effect on growth, sex expression and fruit yield and quality. Ann Agric Sci Moshtohor 36:839-854

Elewa TA, Sadak MS, Saad AM (2017) Proline treatment improves physiological responses in quinoa plants under drought stress. Biosci Res 14(1):21-33

El-Rokiek KG, El-Awadi ME, Abd El-Wahed MSA (2012) Physiological responses of wheat plants and accompanied weeds to derby herbicide and $\beta$-sitosterol bioregulator. J Appl Sci Res 8(4):1918-1926

El-Rokiek KG, El-Din SAS, Messiha NK, Sharara FAA (2014) Effect of guava leaf residue on broad and narrow leaved weeds associated wheat plants. Int J Agric Res 9(7):356-363

El-Rokiek KG, Messiha NK, El-Masry RR, Saad El-Din SA (2011) Evaluating the leaf residues of Eucalyptus globulus and mangifera indica on growth of cynodon dactylon and echinochloa colonum. J Appl Sci Res 7(12): 1793-1799

Fuentes FF, Bazile D, Bhargava A, Martínez EA (2012) Implications of farmers' seed exchanges for on-farm conservation of quinoa, as revealed by its genetic diversity in Chile. J Agric Sci 150:702-716

Gesinski K, Nowak K (2011) Comparative analysis of the biological value of protein of Chenopodium quinoa Willd. and Chenopodium album L. Part I Amino acid composition of the seed protein. Acta Sci Pol Agricultura 10:47-56

González Martín MI, Wells Moncada G, Fischer S, Escuredo O (2014) Chemical characteristics and mineral composition of quinoa by nearinfrared spectroscopy. J Sci Food Agric 94:876-881

Gyamfi MA, Yonamine M, Aniya Y (2002) Free radical scavenging action of medicinal herbs from Ghana Thonningia sanguine on experimentally induced liver injuries. Gen Pharmacol 32:661-667

Hanafy MS, Saadawy FM, Milad SMN, Ali RM (2012) Effect of some natural extracts on growth and chemical constituents of Schefflera arboricola plants. J Hort Sci Ornam Plants 4(1):26-33

Hegazy AK, Farrag HF (2007) Allelopathic potential of Chenopodium ambrosioideson germination and seedling growth of some cultivated and weed plants. Global J Biotechnol Biochem 2(1):1-9

Helmy EMS (1992) Response to summer squash application methods of fresh garlic extracted by different solvents. Alex J Agric Res 37:125-142

Herbert D, Phipps PJ, Strange RE (1971) Chemical analysis of microbial cells. Methods Microbiol 5B:209-344

Kates M, Eberhardt FM (1957) Isolation and fractionation of leaf phospholipids. Can J Bot 35:895-905

Khan W, Balakrishnan P, Smith DL (2003) Photosynthetic responses of corn and soybean to foliar application of salicylates. J Plant Physiol 160(5): 485-492

Khattab H (2007) Role of glutathione and polyadenylic acid on the oxidative defense systems of two different cultivars of canola seedlings grown under saline conditions. Aust J Basic Appl Sci 1(3):323-334

Kuiters AT (1989) Effects of phenolic acids on germination and early growth of herbaceous woodland plants. J Chem Ecol 15(2):468-478

Lichtenthaler HK, Buschmann C (2001) Chlorophylls and carotenoids: measurement and characterization by UV-VIS spectroscopy. In: Wrolstad RE, Acree TE, An H, Decker EA, Penner MH, Reid DS, Schwartz SJ, Shoemaker CF, Sporns $P$ (eds) Current protocols in food analytical chemistry (CPFA). Wiley, New York, pp F4.3.1-F4.3.8

Mady A (2009) Effect of certain medicinal plant extracts on growth, yield and metabolism of some medicinal aromatic and plants. M.Sc., Al - Azher Univ Fac Sci. Botany Microb Dep. 
Martins N, Petropoulos S, Ferreira ICFR (2016) Chemical composition and bioactive compounds of garlic (Allium sativum L.) as affected by pre- and post-harvest conditions: A review. Food Chem. 2016(211):41-50

Nascimento AC, Mota C, Coelho I, Gueifão S, Santos M, Matos AS, Gimenez A, Lobo M, Samman N, Castanheira I (2014) Characterization of nutrient profile of quinoa (Chenopodium quinoa), amaranth (Amaranthus caudatus), and purple corn (Zea mays L.) consumed in the North of Argentina: Proximates, minerals and traceelements. Food Chem 148:420-426

Nowak V, Du J, Charrondière R (2016) Assessment of the nutritional composition of quinoa (Chenopodium quinoa Willd.). Food Chem. 193:47-54

Puva“ca N, Ljubojević D, Lukač D, Borojević M, Kostadinović L, Teodosin S, Stanaćev V (2014) Bioactive compounds of garlic, black pepper and hot red pepper. In: Proc XVI Int Symp, "Feed Technology". Novi Sad, Serbia, pp $116-122$

Rice EL (1984) In Allelopathy, 2nd edn. Academic Press, Orlando, p 422

Sánchez-Chino X, Jiménez- Martínez C, Dávila-Ortiz G, ÁlvarezGonzález I, Madrigal-Bujaidar E (2015) Nutrient and non-nutrient components of legumes, and its chemopreventive activity: a review. Nutr Cancer 24:1-10

Sasikumar K, Vijayalakshmi C, Parthiban KT (2001) Allelopathic effects of four Eucalyptus species on red gram (Cajanus cajan L.). J Tropical Agric 39:134-138

Saturni L, Ferretti G, Bacchetti T (2010) The gluten-free diet: safety and nutritional quality. Nut 2:16-34

Sharma A, Bhardwaj RD, Gupta AK (2015) Ferulic acid: a novel inducer of antioxidant enzymes in wheat (Triticum aestivum L.) seedlings. Cereal Res Communic 43(3):394-402

Sikandar H, Ahmad H, Ali M, Kashif H, Khan MA, Cheng Z, Smith FMA, Gilles JK, Hamilton P (2018) Aqueous garlic extract as a plant biostimulant enhances physiology, improves crop quality and metabolite abundance, and primes the defense responses of receiver plants. Appl Sci 8(5):15. https://doi.org/1 0.3390/app8091505

Singh HP, Batish SN, Kohli RK (2005) Herbicidal activity of volatile oils from Eucalyptus citriodora against Parthenium hysterophorus. Ann Appl Biol 146(1):89-94

Snedecor GW, Cochran WG (1980) In: lowa State University Press (ed) Statistical Methods, 7th edn, Ames

Synge RLM (1971) Proteins and poisons in plant. Nature Wissen Schaftliche Rundschar 24(2):54-61

Tang Y, Li X, Chen PX, Zhang B, Liu R, Hernandez M, Draves J, Massimo FM, Tsao RA (2016) Assessing the fatty acid, carotenoid, and tocopherol compositions of amaranth and quinoa seeds grown in Ontario and their overall contribution to nutritional quality. J Agric Food Chem 64:1103-1110

Vega-Gálvez A, Miranda M, Vergara J, Uribe E, Puente L, Martínez EA (2010) Nutrition facts and functional potential of quinoa (Chenopodium quinoa Willd.), an ancient Andean grain: a review. J Sci Food Agric 90:2541-2547

Wang H, Li X, Shen D, Oiu Y, Song J (2014) Diversity evaluation of morphological traits and allicin content in garlic (Allium sativum L.) from China. Euphytica 198:243-254

\section{Publisher's Note}

Springer Nature remains neutral with regard to jurisdictional claims in published maps and institutional affiliations.

\section{Submit your manuscript to a SpringerOpen ${ }^{\circ}$ journal and benefit from:}

- Convenient online submission

- Rigorous peer review

- Open access: articles freely available online

- High visibility within the field

- Retaining the copyright to your article

Submit your next manuscript at $\boldsymbol{\nabla}$ springeropen.com 